\title{
DISTAL INTERPHALANGEAL JOINT DISEASE AND NAIL ABNORMALITIES
}

\author{
BY \\ FLOYD A. GREEN \\ From the Rheumatology Section, Medical Service, Veterans Administration Hospital, \\ and the Department of Medicine, State University of New York at Buffalo, Buffalo, New York
}

Psoriatic arthritis has now gained general acceptance as an entity distinct from rheumatoid disease (Garrod and Evans, 1924; McEwen, Ziff, Carmel, DiTata, and Tanner, 1958; Wright, 1961). Distal interphalangeal joint involvement is a prominent feature of psoriatic arthritis (Avila, Pugh, Slocumb, and Winkelmann, 1960; Bauer, Bennett, and Zeller, 1941; Sherman, 1952), but not of rheumatoid arthritis (Thould and Simon, 1966). The nail changes so frequently accompanying the distal interphalangeal joint involvement in psoriatic arthritis are not specific findings (White and Laipply, 1952; Pardo-Castello and Pardo, 1960a) and may be noted in Reiter's syndrome (Weinberger, Ropes, Kulka, and Bauer, 1962) as well as in fungal diseases (Samman, 1965; Pardo-Castello and Pardo, 1960b). A syndrome encompassing features of Reiter's disease and psoriatic arthritis has been observed by a number of investigators (Wright and Reed, 1964; Perry and Mayne, 1965; Khan and Hall, 1965). The entity of psoriatic arthritis without psoriasis or nail changes has been described in the course of family studies (Baker, Golding, and Thompson, 1963).

The present report underlines the continuity of disease pattern in patients with nail involvement and distal interphalangeal joint disease, and suggests difficulties in diagnostic categorization. Four selected patients with sero-negative articular disease of 10 or more years duration are described: one with nail and distal interphalangeal joint involvement, but no personal or family history of skin disease of any kind, two with probable "Reiter's disease", one of whom had keratosis blennorrhagica, and one patient with "psoriatic arthritis" or "Reiter's disease".

\section{Case Reports}

Case 1.-A white male accountant, born in 1917, first began to have pain and swelling in several terminal interphalangeal joints of the fingers in 1946, along with nail changes. These symptoms have persisted until the

*Supported in part by U.S.P.H.S. Grant AM-05581. present. In 1952 radiographs of the distal interphalangeal joint of the left index finger showed soft tissue swelling and one small erosion on the ulnar side of the base of the distal phalanx (Fig. 1A). The interphalangeal joints of the thumbs showed extensive erosive changes. Tests for rheumatoid factor were negative. The sacro-iliac joints were negative on radiological examination.

The fingernails and toenails were noted to be variably discoloured, thickened, with terminal separation and subungual hyperkeratosis, but without pitting of any kind (Fig. 1C). Repeated examinations of the nails for infection were negative. There were no skin abnormalities on any of the numerous examinations since 1952, and none that the patient or his wife could recall. The family history was entirely negative. Serial radiographs of the left index distal interphalangeal joint from 1952 to 1967

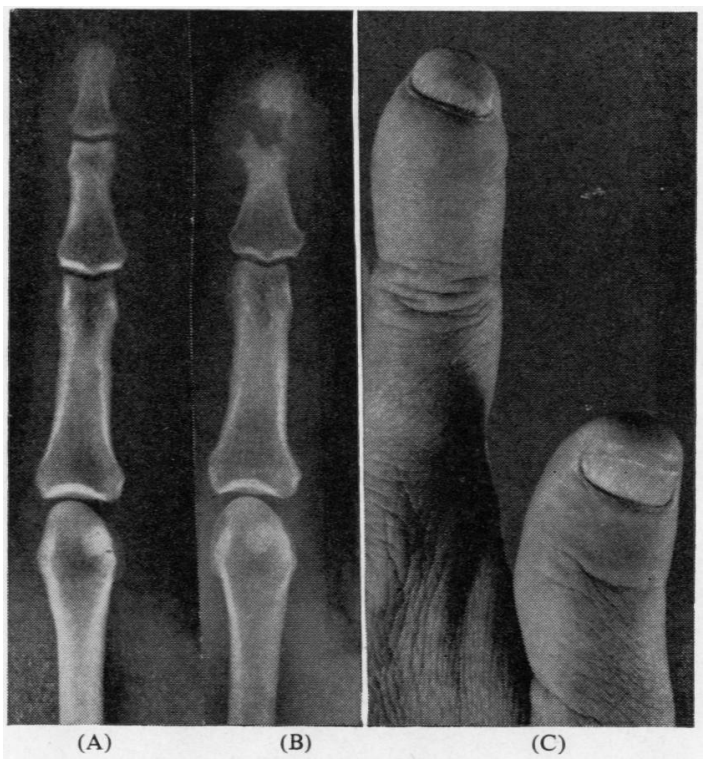

Fig. 1A.-Case 1. Left index distal interphalangeal joint in 1952, showing small erosion on ulnar side of base of distal phalanx. B. Left index distal interphalangeal joint in 1967, showing extensive bone resorption.

C. Clinical photograph of left hand, January, 1967. The nail changes are more prominent in the first and second digits where distal interphalangeal joint changes are in evidence. These nails have been clipped short by the patient to improve appearances (subungual hyperkeratosis). 
showed progressive loss of joint space and bone resorption. Fig. 1B shows the final film in this series. $X$ rays of the feet in January, 1967, showed definite changes only in the interphalangeal joint of the left great toe: soft tissue swelling, joint space narrowing, and bony proliferation.

Case 2. - A white male printer, born in 1912, was well until 1944, when he developed urethritis, possibly gonococcal. No symptoms followed until 1948, when he noted the gradual onset of pain and swelling of the knees, hands, and feet, accompanied by changes in the fingernails and toenails. In 1954 he developed a pustular erythematous eruption of the soles of the feet and between the toes. There were no mucous membrane or genital lesions. Examination of the nails for mycotic infection was negative on numerous occasions.

In 1956 there were vesicular lesions in addition to the hyperkeratotic plaques on the soles of both feet. The sacro-iliac joints were abnormal on radiological examination, and erosive changes were also noted in the apophyseal joints of the cervical spine. A biopsy of the skin of the right sole in 1956 was interpreted as consistent with keratosis blennorrhagica, although it was noted that a definite distinction from pustular psoriasis could not be made.

In 1963 he developed iridocyclitis, with subsequent complete loss of vision in the right eye which was due to secondary glaucoma. In November, 1966, there was swelling and erythema over the proximal and distal interphalangeal joints of the feet. There was no flexion of the lumbar spine, and very reduced movement of the dorsal and cervical spine. The fingernails and toenails were grossly deformed and thickened with separation, partial loss, and subungual hyperkeratosis (Fig. 2A). There were no skin lesions other than on the feet on this occasion, or on any of the three previous hospitalizations, or by history. The family history was negative. Tests for

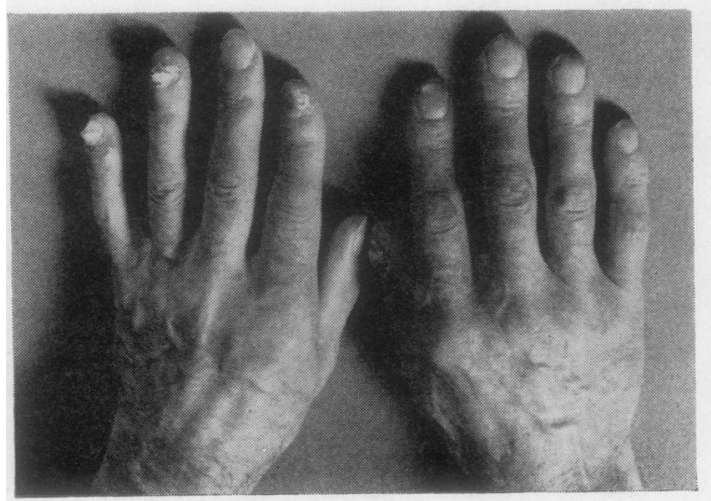

(A) rheumatoid factor (Latex) were negative. Hand films in November, 1966, showed slight loss of joint space of the fourth and fifth left distal interphalangeal joints. Radiơ graphs of the feet showed marked changes (Fig. 2B). $\frac{\square}{\omega}$

Case 3. - A white male steelworker, born in 1937, firs? began to note pain and swelling of the right knee and foot in 1957. Since 1958 he has had distal interphalangea joint involvement of the feet (Fig. 3), and thickening discolouration, brittleness, and distal separation of aA the toenails and thumbnails of the hands. Examinations for nail infection were negative. He also developed severă episodes of conjunctivitis. Urethritis occurred in 1968 from which gonococci were found on smear. The rheuman toid factor test was negative. The sacro-iliac joints we $\vec{E}$ negative on radiological examination. Radiographs of the feet showed changes in the distal interphalangeal join

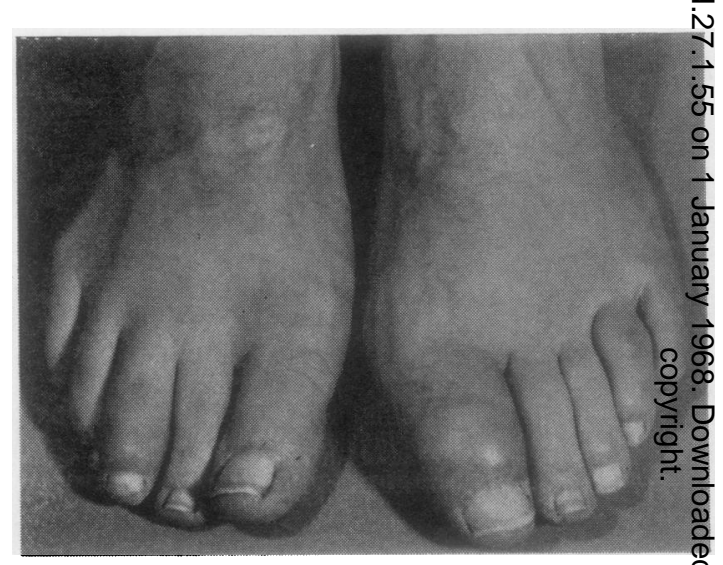

Fig. 3.-Case 3. Clinical photograph of both feet in 1966, showing thickening and discolouration of nails, and swelling of the first left interphalangeal and third right distal interphalangegl joints.

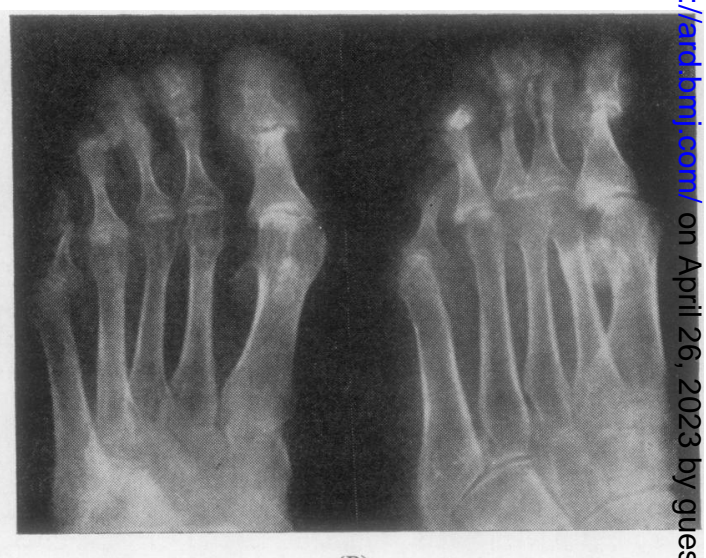

(B)

Fig. 2A. Case 2. Clinical photograph of hands in 1966, showing extensive nail changes in four of the ten fingernails.
B. Radiograph of right foot in 1966 (two views) showing extensive destructive changes of proximal and distal interphalangeal joigts and of metatarso-phalangeal joints. 
corresponding to the areas of chronic clinical involvement.

There has been no clinical or radiological involvement of the distal interphalangeal joints of the hands. The serum was negative for rheumatoid factor. The patient's father was reported to have psoriasis.

Case 4. - A white male stock clerk, born in 1931, was perfectly well until 1954, when he developed a round erythematous lesion of the penis, just proximal to the corona. The lesion gradually increased in size, and was accompanied in 1955 by changes in the fingernails and by a papulosquamous eruption of the scalp. The lesions on the penis and scalp have been noted intermittently to the present. Painful swelling of the distal interphalangeal joints of the thumb and fingers began at the same time and mild activity has continued. The interphalangeal joints of the great toes and the distal interphalangeal joints of the other toes became involved clinically and radiologically (Fig. 4A). The latex test for rheumatoid factor was negative and the erythrocyte sedimentation rate has never been elevated. The nail changes have consisted of thickening, distal separation, discolouration, and large erosions (Fig. 4B). Repeated examination of the nails for mycotic infection has been negative. Serial radiographs of the hands from 1956 to 1967 showed persistent soft tissue swelling and minimal proliferative changes. $X$ rays of the sacro-iliac joint showed possible early sclerotic changes.

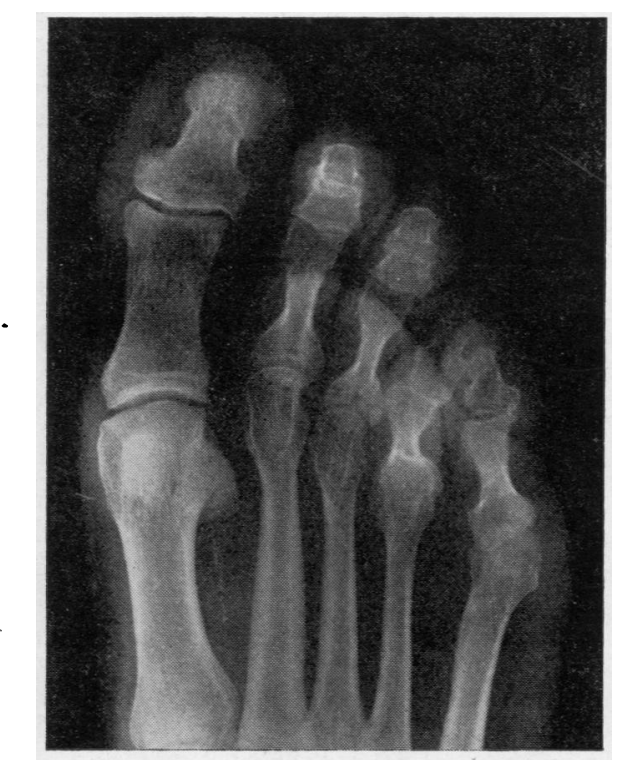

(A)

Fig. 4A.-Case 4. $X$ ray of right foot in 1966, showing soft tissue swelling and subluxation of fourth and fifth metatarso-phalangeal joints, and destruction of fourth and fifth interphalangeal joints (only one interphalangeal joint in fourth and fifth digits). The second and third distal interphalangeal joints are also involved but are not well visualized in this view.

\section{Discussion}

It has been pointed out that nail changes in patients with eczema and exfoliative dermatitis (Pardo-Castello and Pardo, 1960a), as well as mycotic infections (Pardo-Castello and Pardo, 1960b) can mimic the changes in psoriasis. In Case 1 there was no evidence of psoriasis apart from the nails, which did not reveal pitting. Whether Case 1 should be termed psoriatic arthritis is a matter of definition. The course of the arthritis was protracted in the absence of any suggestive evidence of psoriasis in either the patient or his relatives. The nail changes could represent a forme fruste of other skin conditions, including Reiter's disease as well as psoriasis. It is also conceivable that the distal joint disease and nail involvement are both due to chronic infection with an agent difficult to culture.

Both patients whose diagnosis could be termed Reiter's disease (Cases 2 and 3) had extensive nail changes and one had keratosis blennorrhagica (Case 2). Case 4 had been diagnosed as having psoriatic arthritis, but the scalp lesion could have been seborrheic dermatitis and the illness would be otherwise compatible with Reiter's disease. Similar scalp lesions have also been described in Reiter's disease (Hancock, 1960).

One could suggest that the diagnosis in each of these patients was arbitrary. Is the concept of variable disease spectrum to explain "overlap" between Reiter's disease and psoriasis (Wright and Reed,

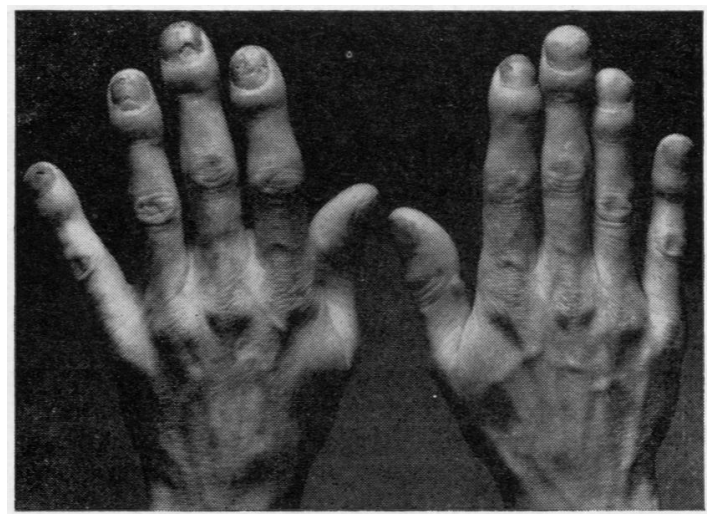

(B)

B. Clinical photograph of both hands in 1967, showing soft tissue swelling of distal interphalangeal joints, and large erosions of nails, with thickening and discolouration. 
1964) a poor parole from the prison of jargon? This "overlap" may represent another illness, different from psoriasis generally, and different from another group of Reiter's. Distal interphalangeal involvement did not appear to be a significant feature of any of the patients with Reiter's disease described by Wright (1963), but was noted in some of the twelve patients described by Wright and Reed (1964) as having features common to Reiter's disease and psoriasis. In a series of 76 patients with Reiter's disease, only those with keratoderma (and only a few of these) appeared to have nail involvement (Hancock, 1960). It is also conceivable that patients with psoriasis and arthritis have a different disease from patients with psoriasis alone. The question of heterogeneity in psoriasis has been raised in the past (Abele, Dobson, and Graham, 1963). Steinberg, Becker, Fitzpatrick, and Kierland (1951) deduced from their studies that at least two genes would be required to explain the familial distribution of psoriasis. Other suggestions of heterogeneity include the more frequent appearance of nail changes with "psoriasis and arthritis" than of changes with "psoriasis" alone, and the observation that some cases of acute psoriasis appear to follow streptococcal infections (Whyte and Baughman, 1964). Pustular psoriasis, acrodermatitis continua, and impetigo herpetiformis have been considered to be subgroups of psoriasis (Lever 1961).

\section{Summary}

Four adult males with significant distal inter phalangeal joint involvement and nail disorder\& other than fine pitting have been followed for 10 t 20 years with repeatedly negative studies for naw. infection and for rheumatoid factor in the serums All the patients had progressive radiologica\$ changes in the distal joints of the hands and/of feet, but none had such changes in the metacarpophalangeal joints, the proximal interphalangeal joints of the hands, or the wrists. None of the patients had unequivocal evidence of psoriasis an two or three of the four might be considered to havहै Reiter's disease, but the pattern of nail and joinit involvement was not typical of that found in other published studies of Reiter's disease.

The concept of a variable disease spectrum between Reiter's disease and psoriasis has been employed by some investigators to describe a somewhat different syndrome, but this approach may obscure othef

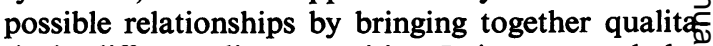
tively different disease entities. It is suggested tha traditional methods of case-indexing be altered to allow studies which can test hypotheses that s\&ge groupings represent different diseases.

\section{REFERENCES}

Abele, D. C., Dobson, R. L., and Graham, J. B. (1963). Arch. Derm. (Chicago), 88, 38 (Heredity and psoriasis).

Avila, R., Pugh, D. G., Slocumb, C. H., and Winkelmann, R. K. (1960). Radiology, 75, 691 (Psoriatic arthritis: a roentgenologic study).

Baker, H., Golding, D. N., and Thompson, M. (1963). Brit. med. J., 2, 348 (Atypical polyarthritis in psoriatic families).

Bauer, W., Bennett, G., and Zeller, J. W. (1941). Trans. Ass. Amer. Physcns, 56, 349 (The pathology of joint lesions in patients with psoriasis and arthritis).

Garrod, A., and Evans, G. (1924). Quart. J. Med., 17, 171 (Arthropathia psoriatica).

Hancock, J. A. H. (1960). Brit. J. vener. Dis., 36, 36 (Surface manifestations of Reiter's disease in the male).

Khan, M. Y., and Hall, W. H. (1965). Arch. intern. Med., 116, 911 (Progression of Reiter's syndrome to psoriatic arthritis).

Lever, W. F. (1961). "Histopathology of the Skin", 3rd ed., p. 122. Lippincott, Philadelphia.

McEwen, C., Ziff, M., Carmel, P., DiTata, D., and Tanner, M. (1958). Arthr. and Rheum., 1, 481 (The relationship to rheumatoid arthritis of its so-called variants).

Pardo-Castello, V., and Pardo, O. A. (1960a). "Diseases of the Nails", 3rd ed., p. 18. Thomas, Springfield, Ill.

- (1960b). Idem, p. 105.

Perry, H. O., and Mayne, J. G. (1965). Arch. Derm. (Chicago), 92, 129 (Psoriasis and Reiter's syndrome).

Samman, P. D. (1965). "The Nails in Disease", p. 24. Heinemann, London.

Sherman, M. S. (1952). J. Bone Jt Surg., 34A, 831 (Psoriatic arthritis: observations on the clinical, roentgenographic, and pathological changes).

Steinberg, A. G., Becker, S. W., Jr., Fitzpatrick, T. B., and Kierland, R. R. (1951). Amer. J. hum. Genet., 3, 267 (A genetic and statistical study of psoriasis). 
Thould, A. K., and Simon, G. (1966). Ann. rheum. Dis., 25, 220 (Assessment of radiological changes in the hands and feet in rheumatoid arthritis).

Weinberger, H. W., Ropes, M. W., Kulka, J. P., and Bauer, W. (1962). Medicine (Baltimore), 41, 35 (Reiter's syndrome, clinical and pathologic observations: a long term study of 16 cases).

White, C. J., and Laipply, T. C. (1952). J. invest. Derm., 19, 121 (Histopathology of nail diseases).

Whyte, H. J., and Baughman, R. D. (1964). Arch. Derm. (Chicago), 89, 350 (Acute guttate psoriasis and streptococcal infection.

Wright, V. (1961). Ann. rheum. Dis., 20, 123 (Psoriatic arthritis: a comparative radiographic study of rheumatoid arthritis and arthritis associated with psoriasis).

(1963). Ibid., 22, 77 (Arthritis associated with venereal disease: a comparative study of gonococcal arthritis and Reiter's syndrome).

— and Reed, W. B. (1964). Ibid., 23, 12 (The link between Reiter's syndrome and psoriatic arthritis).

Atteinte de l'articulation interphalangienne distale et anomalies de l'ongle

\section{RÉSUMÉ}

On étudia les cas de quatre hommes adultes ayant une appréciable atteinte de l'articulation interphalangienne distale et des anomalies unguéales autres que de simples dépressions; pendant 10 à 20 ans on rechercha à plusieurs reprises et toujours en vain des signes d'une infection unguéale et le facteur rhumatoïde dans le sérum. Chez tous ces malades on trouva des altérations radiologiques progressives des articulations distales des mains et/ou des pieds; de telles altérations ne s'observèrent jamais dans les articulations métacarpo-phalangiennes, les interphalangiennes proximales des mains $\mathrm{ni}$ dans les poignets. Aucun de ces malades ne présenta de signes certains de psoriasis et deux ou trois d'entre eux auraient pu être considérés comme cas de maladie de Reiter, mais l'aspect des ongles et de l'atteinte articulaire ne correspondait pas à celui décrit dans d'autres travaux publiés sur cette maladie.

La conception d'un tableau morbide variable incluant la maladie de Reiter et psoriasis a été utilisée par certains chercheurs pour décrire un syndrome quelque peu différent, mais cette approche pourrait masquer d'autres relations possibles en groupant des entités morbides qualitativement différentes. On suggère une modification des méthodes traditionnelles de classification de manière qu'on puisse vérifier les hypothèses selon lesquelles de tels groupements représentent des maladies différentes.

\section{Afección de la articulación interfalangiana distal y anomalías de la uña}

\section{SUMARIO}

Se estudiaron los casos de cuatro hombres adultos con una afección apreciable de la articulación interfalangiana distal y con anomalías de las uñas, con excepción de simples depresiones. Durante 10 a 20 años se buscaron sin éxito signos de infección ungueal y el factor reumatoide en el suero. Todos los enfermos desempeñaron alteraciones radiológicas progresivas en las articulaciones distales de las manos y/o de los pies pero no en las articulaciones metacarpo-falangianas, las interfalangianas proximales de las manos $o$ en las muñecas. Ninguno de estos enfermos mostró evidencia unequívoca de psoriasis y dos o tres de ellos hubieron podido ser considerados como casos de enfermedad de Reiter si no fuera por el hecho de que el cuadro de la afección ungueal y articular no correspondiese al encontrado en otros estudios publicados sobre la enfermedad de Reiter.

El concepto de un cuadro morboso variable incluyendo la enfermedad de Reiter y la psoríasis fué utilizado por ciertos investigadores para describir un sindrome algo diferente, pero tal concepto, al agrupar entidades morbosas cualitativamente diferentes, puede hacer perder de vista otras posibles relaciones. Se sugiere una modificación de los métodos tradicionales de clasificación de manera que se puedan averiguar hipotesis según las cuales tales agrupaciones representen enfermedades diferentes. 